\title{
From Environmental Awareness to Environmental Responsibility: Towards a Stewardship Curriculum
}

\author{
Ajayi C. Omoogun (Corresponding author) \\ Department of Environmental Education, Faculty of Education \\ University of Calabar, Calabar, Cross River State, Nigeria \\ E-mail: omoogun.ajayi@gmail.com
}

Etuki E. Egbonyi

Department of Environmental Education, Faculty of Education

University of Calabar, Calabar, Cross River State, Nigeria

\section{Usang N. Onnoghen}

Department of Environmental Education, Faculty of Education

University of Calabar, Calabar, Cross River State, Nigeria

\author{
Received: April 5, 2016 Accepted: August 5, 2016 Published: August 9, 2016 \\ doi:10.5296/jei.v2i2.9265 URL: http://dx.doi.org/10.5296/jei.v2i2.9265
}

\begin{abstract}
The period of environmentalism heightened environmental concern and subsequently the emergence of Environmental Education that is anchored on awareness. It is thought that increase in environmental awareness will reverse the misuse of the environment and its resources. Four decades after the international call for Environmental Education, Earth's degradation is far from abating as it's pristinity is consistently and irreversibly being eroded by no less than from anthropocentric activities. Humans have seen themselves as the dominant species that is apart and not part of the organisms that constitute the environment. The philosophical value free nature concepts and the theological assumption that human are the ultimate species together with the rise of capitalism and its surrogates consumerism together conspire to diminuate environmental health. To protect the environment therefore, we must refocus EE to change human's view of the environment and attitude towards the utilization of its resources. Environmental education can become more effective in creating
\end{abstract}


respect for the environment. This paper examined the failure of efforts at addressing environmental issues via environmental education. The paper posits that environmental problems are on the increase due to lack of deliberate responsibility and stewardship, lack of a unique EE curricula and ineffective pedagogy. We suggest therefore that EE can target human perception and attitude and direct then towards biocentric stewardship for the environment. This can be achieved through a deliberate pedagogy of environmental values that promotes sustainable attitude and respect for the environment. Humans must bear the burden of responsibility to ensure the wellbeing of the environment. We must replace the philosophical value free nature concepts that nature is a common commodity and the theological assumption that humans are the ultimate species. We must also rethink our consumerism nature and the endless faith in the efficacy of technology to solve reoccurrence human induced ecological problems. These issues must be embedded in the school curriculum. Pedagogical approach to EE should essentially be the experiential model. The school curriculum must be the carrier and doer of these values that are crucial to the sustainability of the environment. Environmental ethics, environmental code of conduct, environmental nationalism, nature as manifestation of God, ascetic consumerism are recommended as key component of environmental curricula and pedagogy.

Keywords: Environmental Education, Environmental awareness, Environmental responsibility, Environmental ethics, Curriculum

\section{Introduction}

The desire of human to continue to subsist on the Earth planet and the very fact that humans have no other planet as habitable and hospitable perhaps led human to start thinking; at first superficially, and in time deeply about the need to protect the earth. It is now well-known fact that the planet earth is losing its biological, physical and chemical capabilities; what is generally referred to as environmental degradation. The period of environmentalism heightened environmental concern and the emergence of Environmental Education that is aimed at creating awareness. It is thought that increase in environmental awareness will reverse the misuse of the environment and its resources. Earth's degradation is far from abating and its pristinity is consistently and irreversibly being eroded by no less than anthropocentric activities. This is evidence from the many environmental problems facing us daily - pollution, waste, ozone layer depletion, acid rain, species extinction etc. Nature has also lost it awesomeness and spirituality. As Urey, Colak, and Okur (2009: p. 795) noted, "environmental problems keep rising in pace with ever-advancing technology and increasing population and the ecological balance is being disturbed day by day".

As noted by the United Nations Environment Programmes, "atmospheric, geological, hydrological, biological and other Earth System processes are being altered by human activity. The most readily recognized changes include a rise in global temperatures and sea levels, and ocean acidification, all associated with the increase in emissions of greenhouse gases, especially carbon dioxide and methane. Other human-induced changes include extensive deforestation and land clearance for agriculture and urbanization, causing species extinctions as natural habitats are destroyed. The scale, spread and rate of change of global drivers are 
without precedent. Burgeoning populations and growing economies are pushing environmental systems to destabilizing limits" (UNEP, 2012: p. 26) This Human expansion has been accompanied by fundamental changes in the scale, intensity and character of society's relationship with the natural world (Steffen et al., 2007; MA, 2005). The Earth is said to entered a new geological epoch, the Anthropocene (Zalasiewicz et al., 2011, 2010), migrating from the Holocene, the interglacial era that has provided humanity, over the past 100 decades years, with extraordinarily rich ecoystems that have sustained and enhanced the development of the modern societies (Folke et al., 2011).

Since the industrial revolution, many economies all the world over have pursued economic growth vigorously and applying sophisticated technology to exploit earth's resources and in many instances modifying the earth in doing so. At first was the assumption that to advance human welfare, we must apply warfare on earth's resources that are also thought to be infinite. Human progress and welfare was hinged on the conquest of the vast wilderness. Increase in fossil fuels, technological advances, population growth and the humongous accelerated human consumption have culminated in altering the biogeochemical balance resulting in pollution and the creation of ecological disorder.

There is also the other perspective of human as being apart from other organism. This anthropocentric view has made human 'biological imperialist' of some sort, invading the earth' resources at will, including invasion of other organism as well as their habitat. In addition, the dominant social paradigm orientation (Kilbourne, Beckman, Lewis, \& Van Dam, 2001) and techocentricism - assumptions that all problems can and will be solved by some application of more technology (Winner, 1986; Postman, 1993), in combination have left no biotic-flora and fauna alike- and abiotic resources escaped human exploitation and consumerism.

Generally, earth's degradation is far from abating and it's pristinity is consistently and irreversibly being eroded due to continuous As habitats disappeared due to human's activities, species began to also vanish and it is currently at an alarming rate, all victims of human expansion and exploitation. Many approaches at curbing earth's destruction that are still practised have been elaborated by Rydings (1998). They include:

$>$ The Rural: land use practices for reducing soil erosion improved irrigation practices optimizing fertilizer applications. Precision in application, soil analysis etc. Proper use of pesticides - precision application and reduced usage. Management of animal manure into compost, reducing wildfires in the case of forestry, application of environmentally sound forestry operations, reseeding, selective felling etc.

$>$ Urban: Environmental mapping and planning, Noise abatement, Integrated waste handling- minimization of waste, Sewage ad urban storm water.

The Energy: Sustainable energy future that does not degrade the earth. New energy sources - solar, wind etc. Energy planning approaches.

The Transportation: Reduction of motor vehicle exhaust through use of converters; and developing new electric and hybrid vehicles. Social and infrastructural changes to combat 
noise air pollution - public transportation, emission norms, combined transportation etc.

$>$ Legislation: environmental laws, policies, regulations, decrees, etc.

$>$ The Scientific and Industrial Response: Environmental quality guidelines, appropriate technology Environmental auditing Environmental Impact Assessment, Safe chemical handling and Eco-design of products.

> Government Response: The International response: Multilateral environmental cooperation through conventions. Harmonization of environmental legislation and policies. Technology transfer and cooperation. Reduction of trans-boundary movements of hazardous waste. Debt for nature swaps. Research and education, Monitoring and information, Regulatory instruments, Eco-labelling of products, etc.

Many of these approaches have been applied for decades with little success in protecting the environment due to lack of commitment to respect the environment and the resources therein.

\section{Emergence of Environmental Education}

The call for Environmental Education that presumably subsumed environmental awareness is an effort directed at reducing the effects of anthropocentric activities on the environment. The intergovernmental conference on Environmental Education convened by UNESCO in cooperation with United Nation Environmental Programme [UNEP] in Tbilisi, in 1977 recommended the development of school curriculum in Environmental Education. According to the Tbilisi Conference, the goals of environmental education include:

i. To foster clear awareness of, and concern about, economic social, political and ecological interdependence in urban and rural areas;

ii. To provide every person with opportunities to acquire the knowledge, values, attitudes, commitment and skills needed to protect and improve the environment; and

iii. To create new patterns of behaviour of individuals, groups and society as a whole towards the environment; (UNESCO, 1978: p. 8).

In support of these goals, the following core objectives of environmental education were proposed:

Awareness: to help social groups and individuals acquire an awareness of and sensitivity to the total environment and its allied problems.

$>$ Knowledge: to help social groups and individuals gain a variety of experience in, and acquire a basic understanding of the environment and its associate problems.

Attitudes: to help social groups and individuals acquire a set of values and feelings of concern for the environment, and motivation for actively participating in environmental improvement and protection.

Skills: to help social groups and individuals acquire the skills for identifying and solving environmental problems. 
Participation: to provide social groups and individuals with an opportunity to be actively involved at all levels in working towards resolution of environmental problems (UNESCO, 1978: pp. 26-27).

Furthermore, the Tbilisi conference endorsed the following guiding principles:

consider the environment in its totality-natural and built, technological and social (economic, political, technological, cultural-historical, moral aesthetic);

$>$ be a continuous lifelong process, beginning at the pre-school level and continuing through all formal and non-formal stages;

be interdisciplinary in its approach, drawing on the specific content of each discipline in making possible a holistic and balanced perspective;

$>$ examine major environmental issues from local, national, regional and international points of view so that students receive insights into environmental conditions in other geographical areas;

$>$ promote the value and necessity, of local, national and international co-operation in the prevention and solution of environmental problems;

explicitly consider environmental aspects in plans for development and growth; enable learners to have a role in planning their learning experiences and provide an opportunity for making decisions and accepting their consequences;

$>$ relate environmental sensitivity, knowledge, problem-solving skills and values clarification to every age, but with special emphasis on environmental sensitivity to the learner's own community in early years;

$>$ help learners discover the symptoms and real causes of environmental problems; emphasize the complexity of environmental problems and thus the need to develop critical thinking and problem-solving skills... (UNESCO, 1978: p. 27).

Environmental Education (EE) is concerned with teaching conceptual knowledge and skills, a process in which individuals gain awareness that will enable them to act and also the development of the values and attitudes which will motivate and empower individuals and groups to work and promote the sustainability to solve present and future environmental problems (GDRC, 2004).

Without any doubt, education is thought to bring the needed changes in human attitude towards the Environment. An ecological literate citizen would have a comprehensive understanding of the Environment and how it works; develop interest about the environment and take actions to protect the environment.

Despite the introduction of EE global ecological decline has shown no sign of abating. To corrupt a saying 'the dogs bark, and the Wagon of ecological degradation keep moving'. Desman (1992) has observed that meetings, declaration may give hope that humanity is thinking of the environment but one needs more evidence that people are taking these ideas seriously. Lynton K. Caldwell provided an insight into the perpetuating variable involved in 
Earth's destruction. According to him, Environmental crisis is an outward manifestation of a crisis in the mind and spirit, the kind of creatures we are and what we must become in order to survive.

For To protect the Earth therefore, we must change human's view of the Earth and its resources. Environmental Education has not provided answers to basic but fundamental questions. Taylor, Nathan, and Coll (2003) asserted that the traditional environmental education is too limited in its scope to bring about the necessary attitudinal changes needed to confront environmental crisis. Eppig (2012) observed that:

EE dabbles in this and that, as it does not have a scientific field of its own missing applied and theoretical perspectives that translate into real student understanding and engagement. Students just parrot what they hear from EE usually from nothing more than an orphanage of unrelated and disconnected environmental ed modules produced by well-intentioned non profits and green corporations without any real action.

\section{From Environmental Education to Stewardship}

\subsection{The Imperative of Environmental Ethics}

Environmental ethics is focused on the area of the development of moral values that looks beyond the mechanistic value of the environment and re-conceptualises our relationship to nature with the view that humans are part and not apart from nature. Environmental Ethics served as a complement to environmental awareness as it promotes a love and respect for nature, our connectedness with other organisms and these serve as motivation to act from the sense of duty for the environment.

Karatas (2014) reiterated that a harmonious relationship between human and nature can be reached through Environmental Ethics as people will be able to understand the real value of nature.

Environmental ethics provide the link that re-establish the Paleolithic consciousness and awesomeness and sacredness of the wild which has been linked to improve wellbeing (Oelschlaeger, 1998). Eco-philosophers have linked modernity to increase alienation from wild nature as we increasingly live in a cyberspace, hyper/virtual reality, online and indoors becoming 'natural aliens and cyborgs' subjected to Nature-Deficit-Disorder' (Louv, 2005).

From the pervasive Dominant Social paradigm (Kilbourne, Beckman, Lewis, \& Van Dam, 2001) of the belief in limitless resource, continuous progress and the necessity of growth; faith in the problem solving abilities of science and technology and nature resources as free gift and common property; we must move back to the inevitability of "limits to growth"; and relegate the importance of preserving the "balance of nature"; and the need to reject the notion that nature exists solely for human use (see Dunlap \& Van Liere, 1978: p. 10).

Environmental Ethics would provide answers to the broad questions of how can we reconcile human to nature? How can we make people respect the mother earth and the resources therein? What is wrong in cutting down trees in order to produce food for the growing population? Why should animals be respected and even given rights? Is the Earth and all the 
resources therein not meant for human consumption? So why do we preserve them at all? Is nature not a free gift to which we owe no moral obligation to anybody? Should not all of us look at nature from our natural inclination and treat nature as such? People from different culture would perceive the same object or situation in quite different ways and the same could have very different values. Our desires, approvals, disapproval, feel of guilt vary from society to society depending on our cultural differences. Can we then have a common approach of relating with the environment and its conservation and protection? Should we not produce more children, have the number power and then exploit our environment our own way and also managing it for our own benefit not for any other. Is this not sustainable development? Who should benefit from the conservation of the forest and wildlife species? Is it the farmer that clears it for food production or the people who need the forest to purify the atmosphere of their industrial effluents? Does not future prediction difficult and uncertain and therefore make future consideration vis-à-vis sustainability a difficult and needles task? All these questions are considered as well as their moral implication in environmental ethics. Moral issues are often put aside where economic considerations are upper most. Are there alternatives to the application of morality in environmental issues thereof? Should we begin to look for other ways of saving our environment? Should the issue of poverty and deprivation not be adequately addressed in order to motivate those so affected to participate in Environmental protection and management? If you want the rural populace to protect the forest, must we not begin to think of alternatives to fuel-wood that match their cooking needs?. If you want them to plant trees, can we ensure that they have enough of the arable crops that would make them feed their family and increase their purchasing power before they can participate in tree planting?

Rolston (2003: p. 517) noted that Environmental ethics is theory and practice about appropriate concern for, values in, and duties regarding the nature; evaluate decisions and actions relevant to nature conservation (Haider \& Jax, 2007: p. 2560) since our knowledge, attitude and individuals' moral stands as well as the social and moral values interact together to determine behavior (Rai \& Sharma, 2011: p. 35). Realistically, Environmental ethics will enable us shift from the dormant approach of human-centeredness where our concern about nature is essentially instrumental value. It should promote moral respect for the intrinsic value for the whole nature-human and non-human (Environmental Ethics Resource Center, 2008).

Historians and researches alike have traced environmental degradation to capitalism, the introduction of large scale industrial production, urban living, religion and civility which not only alter the environment but our perceptions of the environment- wilderness, landscape etc.

\section{Redefining Western Countries Value Orientation}

The interests of the developed economies from history have always been exploitative. The natives are usually lured into obnoxious development paradigms which are so designed as to keep the natives perpetually underdeveloped. This is one reason why many people questioned the need to talk about conservation from the foreigner's perspective. Environmental issues are complex web with the social and cultural conditions forming the most exquisite thread of the 
web. For most experts, this complex weave is usually not considered in analyzing Environmental issues. For instance, how do change the behaviour of a rural dweller that sees the environment as an intricate part of him and his existence without understanding this relationship? Unless we recognize the economic, social and the cultural variables, it would be difficult to address very seriously the issues arising from the use or misuse of the environment.

History has shown us that Nations pursue self-interest and promote economic issues than the general well-being of the environment. The histories of slavery, colonization and neo-colonization are lessons that indicate that the concern for our environment may at best a new biological-imperialism. For instance, why would America, Canada, Britain, Russia, and other developed economies be interested in the conservation of our environment? Why are they not interested in helping us to develop sustainable science and technology, good and efficient transport system, nuclear energy for electricity or even provision of water? Why are they not fighting against capital flight (human and cash) from under and less developed countries to the developed countries? Why are they not fighting against the terminator gene in the advancement and spread the benefit of bio-technology? What of technology of waste management? They can also teach or invest in our waste management.

Curiously, why do we have to conserve our environment and for whom? Many economies are still called developing and poor nations: is it not time such economies explore and exploit the environment with all the technology they can afford to become developed and thereafter contain any destruction? Perhaps poor nations should prefer a modified environment with super highways, industries, nuclear energy, big cities with all the paraphernalia of North American consumerism rather than have the thick forest, the wilderness and country side which are safe haven for the protection of nature and biodiversity that housed the lions, chimpanzee, monkeys etc. The issue of human and capital flight from these 'bushes' to developed economies are pointers to the type of environment that many people desire. The United Nations Organization should launch global renunciation of western consumerism and promotion of ascetic living.

\section{Environmental Code of Conduct for College Graduates}

All graduates across the globe should swear allegiance to the environment. For example, they pledge to protect the environment at all times, promote recycling of waste, participate in mobilizing and mitigating environmental issues like climate change.

\section{Environmental Nationalism}

This is closely linked to code of conduct. Nature must be seen as our first home and our first country. Therefore the ownership of nature must be claimed by all and ipso facto be protected. It is not surprising that dogs, goats cows are not becoming threatened or extinct due to the very fact that they have owners. Let the natives be empowered to own nature, claim the resources therein and then protect that right of possession. This right can be extended to groups, tribes, communities and such rights must be fully respected. According to Louv (2005), "the future will belong to the nature-smart - those individuals, families, businesses, 
and political leaders who develop a deeper understanding of the transformative power of the natural world and who balance the virtual with the real. The more high-tech we become, the more nature we need".

\section{Nature as Manifestation of God}

Humans cannot do without core environmental capitals which are the drivers of life. Life cannot exist without God. This existence is not further possible without air, water, land and the wild. These environmental entities can be the manifestation of God. We suffer when we degrade these entities. Protecting them is protecting the divinity of God whose manifestation is embedded in these vast and wondrous resources. Linking God to nature can be enmeshed in rich fables. For instance, 'God flows in the air, do not pollute the air,' the land is gods footstool, life is nourish from the wild, etc.

\section{Effective Curriculum and Pedagogy}

As Blumstein and Saylan (2007) observed that whereas several environmental issues currently facing us today are caused by over-consumption, changing consumption patterns is not generally a targeted outcome of environmental education. It should be one of the most important lessons that must be taught. They noted that "we need to radically overhaul curricula to teach the conservation of consumable products. Teaching where and how resources come from - that food, clean water, and energy do not originate from supermarkets, taps, and power points - may be an important first step."

Curriculum Development/Content: Environmental Education curricula initiatives are still limited to development of supplementary materials with a thematic approach. Such materials are good but many teachers often ignore such topics especially where emphasis is towards preparing students for external examination. Even where Environmental issues are infused into the traditional subjects e.g. Mathematics, English, Economics; the real intent and implications are more often not emphasized. Any approach (infusion, thematic, etc.) it is important to develop contents area within each area that we teach students not only about environment concepts and precept but how to value it, care for it and take actions to protect it. Ethical value of the environment should be the core pedagogy within the infusion or thematic approach. Subjects like literature can contemplate nature- the wonder of nature and natural world, a place of wonder and power; the arts appeals to the aesthetic sensibilities; the sciences teach nature as part of the web of life in relation to the Paleolithic genome and evolution and moral or religious studies teach nature in relation to respect for otherness and our sense of duty to protect it (Brook, 2010) and as caretakers. But EE must teach what action can be taken to promote respect and care for the environment.

Wolf (2011) stated that "all the book-learning and even relevant field trips "somewhere else" cannot substitute for action that can be taken by students in school and in the immediate surroundings. "Simple" activities like helping with recycling, saving energy by replacing bulbs and turning off lights and caring for trees are perfect entry points into the larger aspects of environmental sustainability." Environmental education should move beyond the walls of the classroom so that students can engage in concrete action and have the opportunity to 
integrate knowledge, skill and attitudes with action. This will propel EE from awareness to action. Projects that add value and promote the wellbeing of the environment should be reflected in curriculum design and implementation. According to Eppig (2012), EE should take some lessons from agriculture - teach issues investigations, activate social and political discourse (which is different than writing letters to the town council), teach critical policy, and train young people to enter careers where stewardship is a daily act, not just an experience in a wilderness setting.

As noted by Environmental Ethics Resource Center (2008) different ideas about the nature of the root causes exist among various groups- deep ecologists, bio- regionalists, indigenous people, eco-feminists, naturalists, economists, politicians and social ecologists. According to Linnanvuori (2013), solving global environmental problems requires a major change of values. The curriculum must invade these various groups and map out the contents of their thinking and then develop pedagogies for learners. As Slater and Lambert (1998) asserted, we value what we consider to be worthwhile and give preferences and priority to those thoughts and ideas that we value. The school should seek to promote values for the environment and have them developed and nurtured until they become deep seated in an individual. We must consider whether our action about the environment is right or wrong in the first place and why and what ought to be the case.

\section{Conclusion and Implication to the Curriculum}

Environmental awareness alone cannot bring about respect for the environmental. The broad focus of environmental education is to equip learners with knowledge of environmental issues with the hope that the knowledge will influence our attitude towards the environment. Essentially, this is not too different from learning environmental science.

No education would be complete if it is not based on the understanding of nature which is ultimately our common home. If the west continues with their capitalist consumerism and we follow the trend in the sub-Sahara, we will denature our home and jeopardize the welfare of other species that constitute the community of life. The following points are very important:

The Pursuant of high standard of living among nations, application of sophisticated technology, over consumption, nuclear threat, unequal distribution of wealth, arm proliferation, corruption, space exploration, and genetic modifications are the real serious threats to the environment. Many of these are herald by the western world who are today key decision maker in United Nations Organization. We must begin the greening of the mind to simple living that portends no threat. This perhaps re-emphasized the need for new ethical orientation. Given the importance of the environment and given the complex nature of this system it is indeed necessary that we promote citizen action on a broad measures and means of defending and protecting the environment. In our reconstructed, technological driven society, many cultures that were hitherto sanctuary for values have been mesmerised by marketization and commodification in a rising capitalist consumerism. If the examples of the western pattern of consumption gets entangled in China, India, Brazil and Nigeria exemplified by the search for energy (fossil fuel), exploration of space (which is now competitive), nuclear expansion, the drives and fantasies toward re-creation through 
biotechnology and nanotechnology among others that put the environment at very unpredictable risks, the climate phenomenon that we currently experience is a tip of the iceberg.

As research confirmed consumption and the environment are intertwined. The DSP model influence the dimensions of materialism and materialism negatively impacted on environmental concern. Environmental concern in turn increased direct and indirect environmental behaviours (Polonsky, Kilbourne, \& Vocino, 2014). Sustainable pattern of consumption must be integrated in the school curriculum.

\section{References}

Blumstein, D. T., \& Saylan, C. (2007). The Failure of Environmental Education (and How We Can Fix It). PLoS Biology, 5(5), 0973-0977.

Brook, I. (2010). Why study environmental ethics? In D. R. Keller (Ed.), Environmental ethics: The big questions (pp. 38-39). West Sussex, Wiley-Blackwell.

Dunlap, R. E., \& Van Liere, K. D. (1978). The "new environmental paradigm": A proposed measuring instrument and preliminary results. Journal of Environmental Education, 9, 10-19. http://dx.doi.org/10.1080/00958964.1978.10801875

Environmental Ethics Resource Center. (2008). Main Approaches in Environmental Ethics. Retrieved from http://www.ecoethics.mrsu.ru/eng/arts/56

Eppig, P. (2012). Comments on Green failure: what is wrong with environmental education. Yale Environment 360 interview: Yale schools of forestry and environmental studies.

Folke, C., Jansson, Å., Rockström, J., Olsson, P., Carpenter, S. R., Chapin, F. S., ... Ebbesson, J. (2011). Reconnecting to the biosphere. Ambio. http://dx.doi.org/10.1007/s13280-011$0184-\mathrm{y}$

Global Development Research Center. (2004). Defining environmental education.

Haider, S., \& Jax, K. (2007). The Application of Environmental Ethics in Biological Conservation: A Case Study From the Southernmost Tip of the Americas. Biodiversity Conservation, 16, 2559-2573. http://dx.doi.org/10.1007/s10531-006-9088-8

Karatas, A. (2014). Environmental Ethics Education as a Tool for the Prevention of Environmental Problems in the Community. European Journal of Sustainable Development, 3(4), 263-268.

Kilbourne, W. E., Beckmann, S. C., Lewis, A., \& Van Dam, Y. (2001). A multinational examination of the role of the dominant social paradigm in environmental attitudes of university students. Environment and Behavior, 33(2), 209-228. http://dx.doi.org/10.1177/ 00139160121972954

Linnanvuori, E. A. (2013). Environmental Issues in Finnish School Textbooks on Religious Education and Ethics. Journal of Humanities and Social Science Education, 1, 131-157.

Louv, R. (2005). Last Child in the Woods: Saving our Children from Nature Deficit Disorder. 
Algonquin Press.

MA. (2005). Ecosystems and Human Well-being: Synthesis. Millennium Ecosystem Assessment. Island Press, Washington, DC.

Oelschlaeger, M. (1991). The idea of wilderness. From Prehistoric to the age of ecology. New Haven: Yale University Press.

Polonsky, M., Kilbourne, W., \& Vocino, A. (2014). Relationship between the dominant social paradigm, materialism and environmental behaviours in four Asian economies. European Journal of Marketing, 48(3/4), 522-551. http://dx.doi.org/10.1108/EJM-07-2011-0351

Postman, N. (1993). Technopoly: The surrender of culture to technology. New York: Vintage Books.

Rolston, H. (2003). Environmental Ethics. In N. Bunnin \& E. P. Tsui-James (Eds.), The Blackwell Companion to Philosophy. Oxford: Blackwell Publishers.

Ryding, S.-O. (1998). Environmental Management. Amsterdam: IUS Press.

Slater, F., \& Lambert, D. (1998). Introduction: Examining Values in Geographical a nd Environmental Education. International Research in Geographical and Environmental Education, 7(2), 140-141. http://dx.doi.org/10.1080/10382049808667565

Steffen, W., Crutzen, P. J., \& McNeill, J. R. (2007). The Anthropocene: are humans now overwhelming the great forces of Nature? Ambio, 36, 614-621. http://dx.doi.org/10.1579/ 0044-7447(2007)36[614:TAAHNO]2.0.CO;2

Taylor, N., Nathan, S., \& Coll, R. (2003). Education for sustainability in regional New South Wales, Australia: An exploratory study of some teachers' perceptions. International Research in Geographical and Environmental Education, 12(4), 291-311. http://dx.doi.org/10.1080/ 10382040308667543

UNEP (United Nations Environment Program). (2006). Environmental Education, Ethics \& Action: A Workbook to Get Started. Retrieved from http://www.unep.org/training/ethics en.pdf

UNESCO (United Nations Educational, Scientific and Cultural Organization). (2002). Education for Sustainability from Rio to Johannesburg: Lessons Learnt from a Decade of Commitment. World Summit on Sustainable Development, 26. August 4, September. Johannesburg, South Africa.

UNESCO (United Nations Educational, Scientific and Cultural Organization). (1978). Intergovernmental Conference on Environmental Education Final Report. Paris. UNESCO.

Urey, M., Colak, K., \& Okur, M. (2009). Regional differences in environmental education of primary education in terms of teacher conceptions. Procedia Social and Behavioural Sciences, 1, 795-799. http://dx.doi.org/10.1016/j.sbspro.2009.01.142

Winner, L. (1986). The whale and the reactor: A search for limits in an age of high 
technology. Chicago: University of Chicago Press.

Wolf, N. (2011). Comments on Green failure: What is wrong with environmental education. Yale Environment 360 interview: Yale schools of forestry and environmental studies.

Zalasiewicz, J., Williams, M., Haywood, A., \& Ellis, M. (2011). The Anthropocene: A new epoch of geological time? Philosophical Transactions of the Royal Society A, 369, 835-841. http://dx.doi.org/10.1098/rsta.2010.0339

Zalasiewicz, J., Williams, M., Steffen, W., \& Crutzen, P. (2010). The new world of the Anthropocene. Environmental Science and Technology, 44, 2228-2231. http://dx.doi.org/ $10.1021 / \mathrm{es} 903118 \mathrm{j}$

\section{Copyright Disclaimer}

Copyright for this article is retained by the author(s), with first publication rights granted to the journal.

This is an open-access article distributed under the terms and conditions of the Creative Commons Attribution license (http://creativecommons.org/licenses/by/3.0/). 